\title{
Yield, its components and pest incidence in mixed intercropping of oats (Avena sativa) and field beans (Vicia faba)
}

\author{
JUHA HELENIUS and PÄIVI RONNI \\ Department of Agricultural and Forest Zoology, University of Helsinki, \\ SF-00710 Helsinki, Finland
}

\begin{abstract}
Seed yields, yield components, pest incidence and damage were examined in two field experiments of mixed intercropping of oats (Avena sativa) with field beans (Vicia faba) in Southern Finland in 1984-1985. The stand types were monocrops and replacement series of mixtures with $2 / 3$ and $1 / 3$ or $1 / 3$ and $2 / 3$ of oats and beans, respectively, on plots treated or not treated with insecticide.

In the first season when the overall performance of the crops was poor and the numbers of the main pest Rhopalosiphum padi (Hom., Aphididae) on oats low, the Land Equivalent Ratio (LER) index indicated an intercropping advantage in the bean yield and a disadvantage in the oat yield, the insecticide treatment having no effect on the overall nor on the relative performance of the component crops. The site used during the second season was of high fertility, thus favouring oats over beans. The LERs indicated no advantage or disadvantage in mixed cropping for either oats or beans when $R$. padi was not controlled. Spraying against $R$. padi improved the performance of oats, the mixture with $1 / 3$ oats showing an advantage over the monocrop. Simultaneously, there were signs $(\mathrm{p}=0.08)$ of a reduction in the relative performance of the beans. The indicative results support the hypothesis of interspecific dynamics in compensatory yielding as an element of improved reliability in intercropping.

The yield components most sensitive to the change in cropping pattern were the number of panicles per plant in oats and the seed weight in beans, both increasing in the mixtures. Compared to known responses to stand density in monocrops, the beans responded to the mixed cropping in a more specific way than the oats.

Mixed cropping increased the numbers of aphids in oats. There were signs of a reduced incidence, but not of a reduced average colony size, of Aphis fabae, and of a reduced rate of notching by Sitona spp. weevils on beans in mixed cropping. The results for damage by the frit fly (Oscinella frit) were inconclusive.
\end{abstract}

Index words: Intercropping, oats, faba bean, yield, yield components, pest numbers, pest damage, Rhopalosiphum padi 


\section{Introduction}

Intercropping can be more profitable than monocropping in certain systems. The advantages of intercropping are due not only to an increased total yield per unit area but also to improved reliability from season to season. The better yield is generally thought to be based on complementarity in the use of available resources; the improvement in reliability is thought to be due to the compensatory dynamics of yield formation in the component crops (see Willey 1979; also TrenBATH 1977). In the case of pest attack or other environmental stress on one of the components, the hypothesis of compensation predicts an increase in the yield of the associated component (Trenbath 1976, Perrin 1977). The ability of the associated crop to compensate depends primarily on the timing of damage in relation to the development stages of the crops and on the availability of resources for compensatory development and growth.

Intercropping of grain legumes with cereals has received special attention in research: it is a widespread practice in many climatic conditions, it produces high nitrogen yields and it requires low nitrogen inputs. In many cases intercropping improves the reliability of the legume component in particular. In the system studied by RaO and Willey (1980), i.e. sorghum/pigeonpea cultivation in India, it was estimated that monocrops would fail once in five to eight years, but intercrops in only one year out of 36. In Finland, intercropping of a mixture comprising $60-70 \%$ field beans (Vicia faba Linnaeus, Fabaceae) and 30$40 \%$ oats (Avena sativa Linnaeus, Poaceae) has given better yield stability as compared to the monocropping of beans (VARIS et al. 1982). Mixed cropping with oats was recommended by the breeder for the Finnish cultivars of faba bean, Mikko and Ukko (HovINEN 1982, 1984).

Intercropping can reduce pest damage (for reviews see Norton 1975, Litsinger and Moody 1976, Perrin 1977, Altieri and LiebMAN 1986). A slight majority of studies report a decrease rather than an increase in pest numbers (Altieri and Letourneau 1982, Risch et al. 1983, BALIDDAWA 1985), but the changes in pest numbers have not been studied sufficiently in relation to the yielding of the crops. The emphasis of this research should be on the possibilities of reducing quantitative and qualitative losses in yield, not on changes in pest numbers per se.

The purpose of the study reported in this paper was to elucidate the effects of mixed cropping on the process of yield formation in oats and field beans. The results are discussed with reference to pest incidence and damage. An attempt was made to test the hypothesis of compensatory yielding from beans in the mixtures in case of damage to oats caused by cereal aphids. Some preliminary findings have been described earlier by HelenIus (1988), and the increase due to mixed cropping in the population densities of the main pests in the system, cereal aphids, was reported separately (Helenius 1989).

\section{Material and methods}

\section{Experimental designs}

Monocrops of oats cv. Puhti and field beans cv. Mikko were compared with mixed intercrops of these two plants in two field experiments, carried out during 1984 and 1985 in Helsinki. The experiments consisted of four different crop types:

(1) Monocrop of oats (notation OOO) with a normal seed density of 500 germinating seeds per $\mathrm{m}^{2}$.

(2) A mixture of $2 / 3$ oats and $1 / 3$ beans (OOB) following the replacement principle (de Wit 1960, see also WiLley 1979): the monoculture sowing density of field beans was 100 germinating seeds per $\mathrm{m}^{2}$, and the OOB mixture was established by drilling $2 / 3 \times 500$ germinating seeds of oats and $1 / 3 \times 100$ germinating seeds of beans per $\mathrm{m}^{2}$.

(3) A mixture of $1 / 3$ oats and $2 / 3$ beans (OBB). The OBB mixture was established by 
following the same replacement principle used for the $\mathrm{OOB}$ mixture.

(4) Monocrop of beans (BBB) with a normal seed density of 100 germinating seeds per $\mathrm{m}^{2}$.

The mixtures were established by drilling the seed mixture, and in every case the achieved seedling density was lower than the targeted one (see Results, Fig. 2). The spacing between rows was $125 \mathrm{~mm}$ in all stand types. The rates of nitrogen fertilization were $80 \mathrm{~kg} / \mathrm{ha}$ for OOO, $40 \mathrm{~kg} / \mathrm{ha}$ for OOB and $\mathrm{OBB}$, and $0 \mathrm{~kg} / \mathrm{ha}$ for BBB.

Experiment I (1984) employed a factorial split-plot design with crop type as the main plot factor having four levels, and abundance of cereal aphids as the sub-plot factor having two levels (i.e. one not sprayed and one sprayed with insecticide). The plot size was $10 \mathrm{~m} \times 10 \mathrm{~m}$. The sub-plot in which the cereal aphids were controlled consisted of a $2.5 \mathrm{~m} \times$ $10 \mathrm{~m}$ strip running across the plot. In the spraying $0.75 \mathrm{l} / \mathrm{ha}$ of dimethoate was applied on 19 June at oats G.S. 31 (decimal code for the growth stages of cereals, see Totrman and BROAD 1987), 6 days before the beans started flowering. There were three replications (blocks).

Experiment II (1985) followed a completely randomized block design with three blocks. All the eight factorial treatment combinations, i.e. four stand types times two spraying levels (unsprayed or sprayed), were randomized within each block on plots $7.3 \mathrm{~m}$ long and ten rows wide (gross width $1.5 \mathrm{~m}$ ). In the sprayings $6.25 \mathrm{~g} /$ ha deltamethrin was applied, for the first time on 20 June at oats G.S. 21 and for the second time on 3-4 July at oats G.S. 30 , the same time as when the first bean flowers opened. Benomyl $(750 \mathrm{~g} / \mathrm{ha})$ was applied to protect beans against bean leaf pathogens (Botrytis cinerea Pers. ex Fr., Ascochyta sp.) on 3 July over the whole experiment area.

\section{Sampling for pests}

In Experiment $I$ the sampling for insect pests was done in the unsprayed sub-plots only, while in Experiment II the sprayed plots were also sampled.

Cereal aphid populations were monitored by taking random samples of $60-400$ oat tillers per plot in situ, usually twice a week. Care was taken to avoid damaging the tillers or the insects on the tillers during inspection. Total numbers and the numbers of alatae adults of the aphids, Rhopalosiphum padi (Linnaeus), Sitobion avenae (Fabricius) and Metopolophium dirhodum (Walker) (Hom., Aphididae), were recorded for each tiller sampled. The score estimation method described by LOWE (1984) was applied in certain cases in Experiment II. The cumulative numbers of $R$. padi were calculated as aphid days in an analogous way to degree days (e.g. RUPPEL 1983). Mild visible symptoms of barley yellow dwarf virus (BYDV) were found on $8 \%$ of the plants in all the stand types when sampled on 15 August (Experiment $\mathrm{I}, \mathrm{n}=1118$ ) and 18 July (Experiment II, $\mathrm{n}=144$ ).

The infestation level was estimated as the proportion of oat stems infested by Oscinella frit (Linnaeus) (Dipt., Chloropidae) in Experiment $\mathrm{I}$ using guadrat plant samples $(2 \times$ $0.25 \mathrm{~m}^{2}$ per plot) on 25 June (G.S. 39). The same sampling procedure was applied on 23 July (G.S. 70) in order to estimate the infestation of adventive tillers. As the incidence was very low, being concentrated on late adventive tillers in particular, it was not estimated in Experiment II.

Fifty stems per plot on 18 and 31 July in Experiment $I$ and 10 stems per plot on 11 July in Experiment II were sampled for $A p h i s f a-$ bae Scopoli and Acyrthosiphon pisum (Harris) (Hom., Aphididae) on beans. The scores were estimated in all cases except for $A$. pisum in Experiment I, where the numbers were actually counted.

An estimate of the relative abundances of bean weevils in the genus Sitona Germar (Col., Curculionidae) in Experiment I was obtained by comparing the pitfall catches. Pitfall trapping was carried out in order to assess the activity abundances of epigeig polyphagous predators (in preparation). The traps 
consisted of two plastic cups (diameter $80 \mathrm{~mm}$ ) in the two sub-plots of each plot where the ingress of epigeic arthropods was manipulated. The incidence of notching was low and was not estimated. No pitfall trapping was carried out in Experiment II, and notching by Sitona was estimated by counting the numbers of notches in the lowest leaf of at least three leaflets in a sample of 10 stems per plot.

\section{Analysis of yields}

Two $0.25 \mathrm{~m}^{2}$ quadrats per plot were sampled from Experiment $\mathrm{I}$, and $3 \times 1$ row meters of oats, $3 \times 2$ row meters of beans per plot from Experiment II, in order to estimate the densities and yield components of oats and beans just before harvest, at oats G.S. 91 . Only the unsprayed plots were included in Experiment $\mathrm{I}$.
The plots were harvested using a plot combine. Seed moisture levels were determined at harvesting in order to estimate the degree of ripeness. The seed lots were dried, sorted by species, weighed and, after determination of the moisture content, the yields per unit area at $15 \%$ moisture content calculated. Average seed weights ( 1000 seed weight) were determined, but only for the unsprayed treatments in Experiment I. The total nitrogen content of the seed yields was determined by the Kjeldahl method in Experiment II.

Calculation of the land equivalent ratio, LER (Willey 1979, MeAd and Willey 1980), was based on the achieved seedling densities, not on the seeding rates. This was done in order to improve the biological interpretability of the LERs. The divisor for the control mixtures was the yield of the control monocrop, and the divisor for the sprayed mixture was

Table 1. Comparison of treatment means of seed yields $(\mathrm{kg} / \mathrm{ha})$ of oats and field beans in control plots and plots sprayed against cereal aphids on the monocrops and the mixtures. Analysis of variance for the treatment effects.

\begin{tabular}{|c|c|c|c|c|c|c|}
\hline & & Monocrop & & $\begin{array}{c}\text { OOB mixture } \\
2 / 3 \text { oats }+ \\
1 / 3 \text { beans }\end{array}$ & & $\begin{array}{c}\text { OBB mixture } \\
1 / 3 \text { oats }+ \\
2 / 3 \text { beans }\end{array}$ \\
\hline \multicolumn{7}{|l|}{ Exp. I (1984) } \\
\hline $\begin{array}{ll}\text { Oats control } \\
\text { sprayed }\end{array}$ & & $\begin{array}{c}3074(408) \\
3465(157) \\
\text { a }\end{array}$ & & $\begin{array}{l}2272(663) \\
2268(844) \\
\quad \text { b }\end{array}$ & & $\begin{array}{ll}828 & (210) \\
839 & (254) \\
c & \end{array}$ \\
\hline $\begin{array}{r}\text { Beans control } \\
\text { sprayed }\end{array}$ & & $\begin{array}{lll}1 & 169 & (322) \\
1 & 027 & (302)\end{array}$ & & $\begin{array}{l}736(251) \\
857(210)\end{array}$ & & $\begin{array}{lll}1 & 146 & (258) \\
1 & 053 & (272)\end{array}$ \\
\hline \multicolumn{7}{|l|}{ Exp. II (1985) } \\
\hline $\begin{array}{ll}\text { Oats } & \begin{array}{l}\text { control } \\
\text { sprayed }\end{array}\end{array}$ & & $\begin{array}{rrr}4 & 538 & (730) \\
5 & 859 & (74) \\
\text { a } & \end{array}$ & & $\begin{array}{l}2612(244) \\
4605 \\
\quad \text { b }\end{array}$ & & $\begin{array}{lll}1 & 797 & (383) \\
3 & 056 & (212) \\
& c & \end{array}$ \\
\hline $\begin{array}{r}\text { Beans control } \\
\text { sprayed }\end{array}$ & & $\begin{array}{ll}559 & (115) \\
517 & (118) \\
\mathrm{a} & \end{array}$ & & $\begin{array}{ll}282 & (70) \\
178 & (50) \\
\text { b } & \end{array}$ & & $\begin{array}{l}480(140) \\
330(134) \\
b\end{array}$ \\
\hline Analysis of variance: & & & & & & Beans \\
\hline source & year & & df & F-value & df & F-value \\
\hline crop type & $\begin{array}{l}1984 \\
1985\end{array}$ & & $\begin{array}{l}2 / 4 \\
2 / 10\end{array}$ & $\begin{array}{l}31.0^{* * *} \\
63.9^{* * *}\end{array}$ & $\begin{array}{l}2 / 4 \\
2 / 10\end{array}$ & $\begin{array}{r}1.2 \mathrm{~ns} \\
12.0^{* *}\end{array}$ \\
\hline spraying & $\begin{array}{l}1984 \\
1985\end{array}$ & & $\begin{array}{l}1 / 6 \\
1 / 10\end{array}$ & $\begin{array}{c}2.3 \mathrm{~ns} \\
57.5^{* * *}\end{array}$ & $\begin{array}{l}1 / 6 \\
1 / 10\end{array}$ & $\begin{array}{l}0.2 \mathrm{~ns} \\
3.7\left(^{*}\right)\end{array}$ \\
\hline interaction & $\begin{array}{l}1984 \\
1985\end{array}$ & & $\begin{array}{l}2 / 6 \\
2 / 10\end{array}$ & $\begin{array}{l}2.2 \mathrm{~ns} \\
1.4 \mathrm{~ns}\end{array}$ & $\begin{array}{l}2 / 6 \\
2 / 10\end{array}$ & $\begin{array}{l}0.9 \mathrm{~ns} \\
0.7 \mathrm{~ns}\end{array}$ \\
\hline block & $\begin{array}{l}1984 \\
1985\end{array}$ & & $\begin{array}{l}2 / 4 \\
2 / 10\end{array}$ & $\begin{array}{l}2.6 \mathrm{~ns} \\
0.5 \mathrm{~ns}\end{array}$ & $\begin{array}{l}2 / 4 \\
2 / 10\end{array}$ & $\begin{array}{l}0.2 \mathrm{~ns} \\
1.0 \mathrm{~ns}\end{array}$ \\
\hline
\end{tabular}

Standard deviations given in brackets. Significant differences between stand types are indicated by letters within-row. 
the yield of the sprayed monocrop (see OYEJOLA and MEAD 1982).

\section{Statistical procedures}

Analysis of variance procedures were applied to the LERs as robust means of comparisons (see OYEJOLA and MEAD 1982). Frequency tables for mortality rates (binomial case with logit link) or pest incidences (Poisson case with log link) were analysed by log linear models (LOGLIN) using the GLIM package (BAKER and NeldER 1978). Student's t-test was referred to by lowercase t. 10, 5, 1 and $0.1 \%$ risk levels were indicated by $(*)$, $*,{ }^{* *}$ and ${ }^{* * *}$, respectively. If not reported the result of the analysis of variance tests for the interaction term was not significant.

\section{Results}

\section{Seed yields}

The average monocrop yield of oats in Experiment I was only two thirds of that in Experiment II, but the average monocrop yield of beans in Experiment I was twice that in Experiment II (Table 1).

Mixed cropping decreased the yield $(\mathrm{kg} / \mathrm{ha})$ of oats. As expected, the decrease was the greater the higher the proportion of beans in the mixture. The yield of beans was not significantly reduced in the mixtures in Experiment I, but in Experiment II the absolute yield of beans was significantly lower in the OOB mixture than in the OBB mixture, or in the monocrop (Table 1).

In Experiment I the spraying treatment did not have any significant effect on the yield of either oats or beans. In Experiment II the deltamethrin treatment significantly increased the yield of oats in all the crop types. However, there were signs that the spraying reduced the yields of beans ( $\mathrm{p}=0.08$ in the F-test) (Table 1). The average increase in the oat yield and reduction in the bean yield was largest in

the mixtures (proportional change due to spraying, $\%$ ):

$\begin{array}{lrrrr} & \text { OOO } & \text { OOB } & \text { OBB } & \text { BBB } \\ \text { oats } & +29 & +76 & +70 & \\ \text { beans } & & -37 & -31 & -8\end{array}$

However, the interaction of spraying $\times$ crop type was not significant.

The relative performance of oats as measured by the LER index varied in relation to the yield level of beans, and it was affected most in the extreme OBB mixtures. At the relatively high level in Experiment $\mathrm{I}$, the LER $_{\text {oats }}$ in the OBB mixture was significantly lower than the $\mathrm{LER}_{\mathrm{E}}$ (i.e. LER exptected on the basis of the relative seedling density) $\left(\mathrm{t}=2.63^{*}, \mathrm{df}=5\right)$, but at the low level of bean yield in Experiment II the opposite was true. In the sprayed OBB mixture the $\mathrm{LER}_{\text {oats }}$ was significantly higher than the $\operatorname{LER}_{E}\left(t=8.80^{*}\right.$, $\mathrm{df}=2$ ) (Fig. 1). The relative yields in the

EXP. I

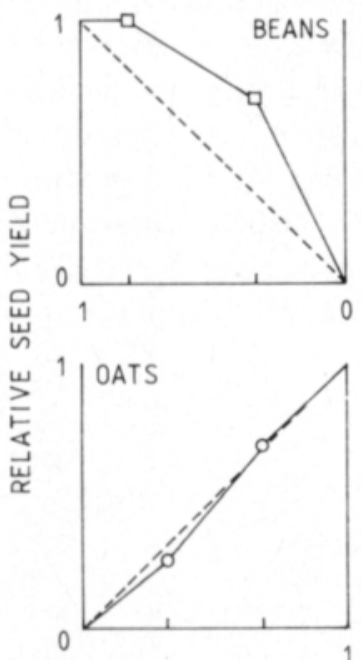

EXP.II
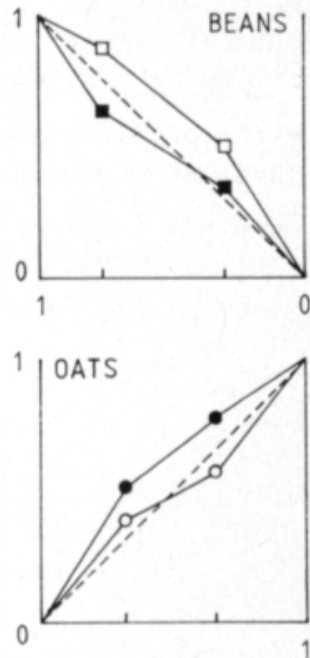

RELATIVE SEEDLING DENSITY

Fig. 1. Relative (LER) seed yields of oats and beans plotted against seedling densities in the OOB (sowing rate $2 / 3$ oats $+1 / 3$ beans) and $O B B$ $(1 / 3$ oats $+2 / 3$ beans) mixtures in control plots (open dots) or plots sprayed against cereal aphids (black dots). Dashed linear lines indicate relative yields proportional to seedling density, i.e. no advantage or disadvantage of intercropping as compared to the case when starting with the same number of seedlings as a monocrop. 
sprayed mixtures were higher than the relative yields in the control mixtures for all crop types $\left(\mathrm{F}=16.99^{* *}, \mathrm{df}=1,6\right)$.

The relative performance of the beans was significantly improved by mixed cropping in Experiment I, where the LERbeans in the OOB mixture was significantly higher than the $\mathrm{LER}_{\mathrm{E}}\left(\mathrm{t}=4.39^{* *}, \mathrm{df}=5\right.$ ) (Fig. 1). In Experiment II the LER values for beans did not significantly deviate from the expectations. However, there were signs that spraying reduced the $\mathrm{LER}_{\text {beans }}(\mathrm{F}=4.47, \mathrm{p}=0.08, \mathrm{df}=1,6)$ (Fig. 1).

\section{Yield components in oats}

In Experiment I there was significant mortality from seedling stage to harvest $(\mathrm{F}=$ $\left.36.1^{* * *}, \mathrm{df}=1,6\right)$. The estimated mortality rates were $40 \%$ in the monocrop, $35 \%$ in the OOB and $32 \%$ in the OBB mixture $(\mathrm{F}=$ 4.2(*), df $=2,6$ ) (Fig. 2).

The number of panicles per plant increased with a decreasing proportion of oats in the stand $\left(\mathrm{F}=62.5^{* *}, \mathrm{df}=2,4\right)$ : on an average $34.2 \%, 39.4 \%$ and $46.5 \%$ of the panicles were on adventive tillers in the monocrop, in the OOB mixture and in the OBB mixture, respectively (Fig. 3). Tillers consistently produced smaller panicles: on an average 27.6 grains/panicle $(\mathrm{SE}=1.8, \mathrm{n}=9)$ as opposed to
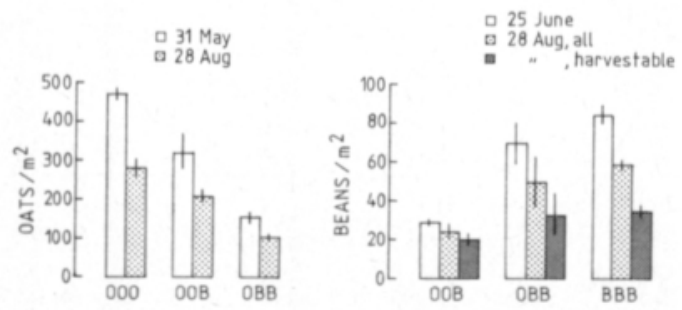

Fig. 2. Seedling densities (open bars) and densities at harvest (dotted bars) of oats and beans, and harvestable densities of beans (dark bars) in the monocrops and mixtures (Experiment I). (Oats monocrop, mixture with $2 / 3$ oats and $1 / 3$ beans, mixture with $1 / 3$ oats and $2 / 3$ beans and beans monocrop are indicated by OOO, OOB, OBB and BBB, respectively. Vertical lines indicate S.E.)

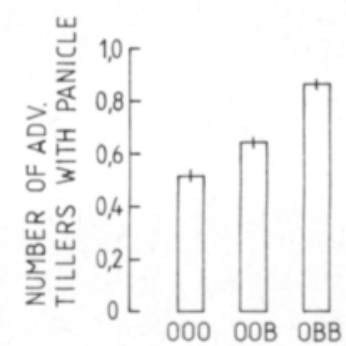

Fig. 3. Number of adventitious tillers bearing panicles per plant in oats in the monocrop and mixtures (Experiment I). (Vertical lines indicate S.E.)

46.6 grains/panicle $(\mathrm{SE}=2.8, \mathrm{n}=9)(\mathrm{F}=$ $\left.74.0^{* * *}, \mathrm{df}=1,6\right)$ for the main stem. In Experiment $I$, the average size of the panicles on the main or adventive stems (as number of grains per panicle) was not influenced by intercropping $(\mathrm{F}=0.5$ n.s., $\mathrm{df}=2,4)$.

In Experiment II, the average size of the panicles was 40.1 grains/panicle $(\mathrm{SE}=1.0$, $\mathrm{n}=3$ ) in the unsprayed monocrop, 42.3 $(\mathrm{SE}=2.5)$ in the unsprayed $\mathrm{OOB}$ mixture and $47.0(\mathrm{SE}=1.0)$ in the unsprayed OBB mixture, but $45.5(\mathrm{SE}=0.8)$ in the sprayed monocrop, $51.0(\mathrm{SE}=0.5)$ in the sprayed OOB mixture and $54.4(\mathrm{SE}=1.8)$ in the sprayed OBB mixture. Thus, the panicle size was increased up to $18 \%$ by intercropping $\left(\mathrm{F}=6.0^{*}, \mathrm{df}=1,6\right)$. Spraying against cereal aphids increased the panicle size by $16 \%\left(\mathrm{~F}=19.9^{* *}, \mathrm{df}=1,6\right)$ in all crop types.

Neither mortality nor tillering of oats were measured in Experiment II. The density of the panicles in relation to seedling density was $1.00(\mathrm{SE}=0.06, \mathrm{n}=6)$ in the monocrop, 1.02 $(\mathrm{SE}=0.06)$ in the OOB mixture and significantly greater, $1.36(\mathrm{SE}=0.08)$, in the $\mathrm{OBB}$ mixture $\left(\mathrm{F}=46 \cdot 0^{* * *}, \mathrm{df}=2,10\right)$. As a result of mortality after seedling emergence, these figures are likely to underestimate the formation of panicle-bearing tillers per surviving plant. The relative differences between stand types in the densities of harvestable panicles were less than those in the seedling densities (Fig. 4).

Spraying significantly increased the ratio between panicle density and seedling density by $15 \%$, irrespective of stand type $(\mathrm{F}=$ 

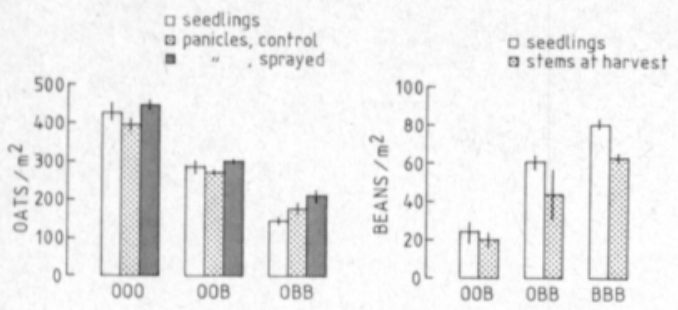

Fig. 4. Seedling densities (open bars), densities of stems bearing panicle in oats not sprayed (dotted bars) or sprayed (dark bars) against cereal aphids, and densities of harvestable stems in beans (dotted bars) in the monocrops and mixtures (Experiment II). (Vertical lines indicate S.E.)

$\left.20.9^{* * *}, \mathrm{df}=1,10\right)$. Correspondingly, the estimated increase due to spraying in the number of panicles per unit area was $14 \%(\mathrm{~F}=$ $10.8^{* *}, \mathrm{df}=1,10$ ) in all crop types (Fig. 4).

The 1000 seed weight (after sorting) was not influenced by intercropping. In Experiment $\mathrm{I}$ the average was $36.1 \mathrm{~g}$. In Experiment II the sprayings significantly increased the 1000 seed weight by $7.3 \%$ : on the control plots the average was $30.2 \mathrm{~g}(\mathrm{SE}=0.40, \mathrm{n}=9)$ and on the sprayed plots $32.4 \mathrm{~g}(\mathrm{SE}=0.48$, $\mathrm{n}=9)\left(\mathrm{F}=18.2^{* *}, \mathrm{df}=1,10\right)$.

\section{Yield components in beans}

The secondary shoot formation of the beans was negligible and the density of the stems reflected the total density of beans in autumn. In Experiment $\mathrm{I}$, the mortality rate of the beans from seedling stage to harvest averaged $27 \%\left(\mathrm{~F}=5.4\left(^{*}\right), \mathrm{df}=1,6\right)$ (Fig. 2) and in Experiment II it averaged $21 \%$ (determined as loss of stems from seedling stage to harvest) and was significant $\left(\mathrm{F}=18.3^{*}, \mathrm{df}=1,4\right.$, Fig. 4). The mortality did not depend on stand type (Experiment I, F=2.0 n.s., df =2,6; Experiment II, $\mathrm{F}=2.2$ n.s., $\mathrm{df}=2,4$ ). Spraying against cereal aphids had no effect on mortality (Experiment II, F $=0.02$ n.s., df $=1,4$ ).

In Experiment I there was an additional loss of pod-bearing stems due to lodging and subsequent rotting of $42 \%$ in the monocrop, $35 \%$ in the OBB mixture and $17 \%$ in the
OOB mixture. Mixed cropping reduced the rate of lodging significantly (LOGLIN, logit, $\left.\Delta \mathrm{G}^{2}=7.6^{*}, \mathrm{df}=2\right)$. Owing to plant mortality or losses due to lodging, the harvestable density of the beans was not significantly higher in the monocrop than in the mixtures $(\mathrm{F}=3.8$ n.s., $d f=2,4)$. The losses of beans were relatively higher in the monocrop than in the mixtures (Fig. 2).

The number of pods per stem did not vary significantly between stand types. In Experiment $I$ the average number was 9.4 , in the lodged plants only 3.2 . Thus, the loss in yield due to lodging was relatively less than the loss in density due to lodging. In Experiment II the number of pods averaged $6.2(\mathrm{SE}=0.4, \mathrm{n}=9)$ in the control plots and $4.7(\mathrm{SE}=0.4, \mathrm{n}=9)$ in the sprayed plots: deltamethrin sprayings significantly reduced pod formation $(\mathrm{F}=$ $14.2^{* *}, \mathrm{df}=1,10$ ).

The number of seeds per pod in the harvestable beans averaged 3.2 and 2.3 in Experiments I and II, respectively. The pod size was not affected by intercropping (Experiment I, $\mathrm{F}=0.03$ n.s., $\mathrm{df}=2,4$; Experiment $\mathrm{II}, \mathrm{F}=0.3$ n.s., $\mathrm{df}=1,6$ ) or by sprayings (Experiment II, $\mathrm{F}=0.4$ n.s., $\mathrm{df}=1,6$ ).

The 1000 seed weight was highest in the OOB mixture and decreased significantly with an increasing proportion of beans in the stand (Experiment I, $\mathrm{F}=196.6 * * *$, $\mathrm{df}=2,4$; Experiment II, $\mathrm{F}=13 \cdot 4^{* *}, \mathrm{df}=2,10$ ). It was not affected by the aphicide sprayings $(\mathrm{F}=0.0 \mathrm{n} . \mathrm{s}$., $\mathrm{df}=1,10$ ) (Fig. 5)

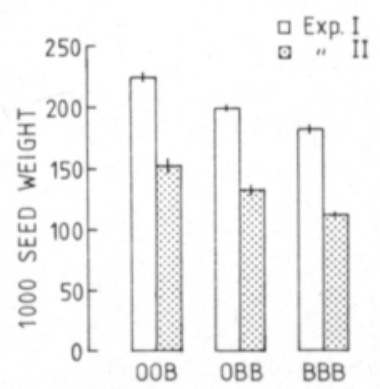

Fig. 5. The 1000 seed weight of beans in the final yield in the monocrop and mixtures (Experiments I and II). (Vertical lines indicate S.E.) 
OATS

a control

a sprayed
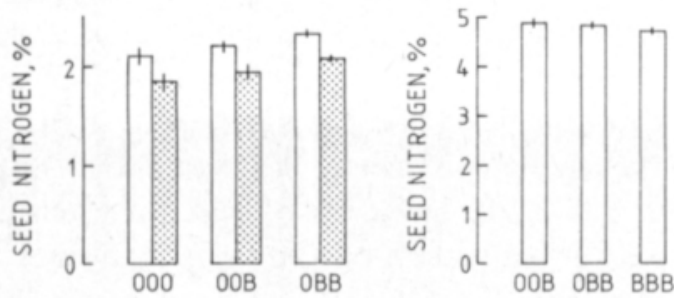

Fig. 6. Total nitrogen content $(\%)$ in oat seeds not sprayed (open bars) or sprayed against cereal aphids (dotted bars), and in bean seeds in the monocrops and mixtures (Experiment II). (Vertical lines indicate S.E.)

\section{Nitrogen Yield}

Data were obtained from Experiment II only. Mixed intercropping slightly but significantly increased the total nitrogen content of the oat $\left(\mathrm{F}=6.3^{*}, \mathrm{df}=2,10\right)$ and bean seeds $\left(\mathrm{F}=9.6^{* *}, \mathrm{df}=2,10\right)$. Deltamethrin treatment had no effect on the nitrogen content of the beans $(\mathrm{F}=0.0 \mathrm{n} . \mathrm{s}$., $\mathrm{df}=1,10)$ but decreased that of the oats significantly $\left(\mathrm{F}=25.9^{* * *}\right.$, $\mathrm{df}=1,10$ ), by $12 \%$ in all stand types (interaction crop type $\times$ treatment not significant, $\mathrm{F}=0.0 \mathrm{~ns}, \mathrm{df}=2,10$ ) (Fig. 6).

The increase in the oat seed yield more than compensated for the lower nitrogen content in the sprayed plots. The highest total nitrogen yield, as estimated from the average seed yields and nitrogen contents, was obtained from the sprayed monocrop of oats, the lowest from the sprayed monocrop of beans (Table 2).
OATS a control a sprayed
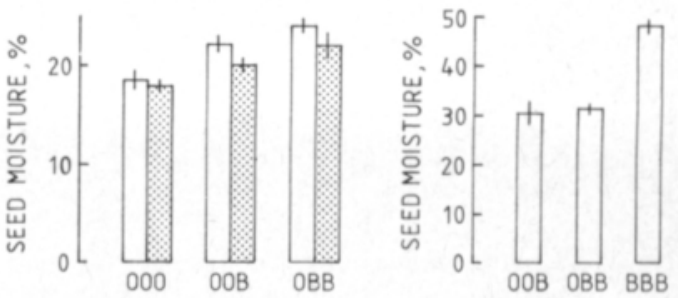

Fig. 7. Moisture content ( $\%$ water) at harvest in oat seeds not sprayed (open bars) or sprayed against cereal aphids (dotted bars), and in bean seeds in the monocrops and mixtures (Experiment II). (Vertical lines indicate S.E.)

\section{Crop maturity}

An indirect estimate of crop maturity at harvest was obtained by measuring the moisture content of the seeds.

In Experiment I the seed moisture content averaged $30.4 \%(\mathrm{SE}=0.7, \mathrm{n}=9)$ in oats and $42.3 \%(\mathrm{SE}=0.9)$ in beans. There were no statistically significant differences between stand types (oats $\mathrm{F}=1.1$ n.s.; beans $\mathrm{F}=0.8$ n.s., $\mathrm{df}=2,8$ ). In Experiment II, the moisture content of oats at harvest was significantly increased by intercropping $\left(\mathrm{F}=17.4^{* * *}, \mathrm{df}=\right.$ 2,10 ). Spraying slightly but significantly reduced the moisture content at harvest, equally in all stand types $\left(\mathrm{F}=6.0^{*}, \mathrm{df}=1,10\right)$. The moisture content in beans was significantly decreased by intercropping $\left(\mathrm{F}=27.8^{* * *}\right.$, $\mathrm{df}=2,10$ ); but was not affected by spraying $(\mathrm{F}=0.6$ n.s., $\mathrm{df}=1,10)$ (Fig. 7).

Table 2. Nitrogen yields $(\mathrm{kg} / \mathrm{ha})$ as calculated by multiplying the treatment means of seed yields by the means of seed nitrogen content (proportion of total $\mathrm{N}$ ) in control $(\mathrm{C})$ and sprayed $(\mathrm{S})$ plots on the monocrops and the mixtures.

\begin{tabular}{|c|c|c|c|c|c|c|c|c|}
\hline & \multicolumn{2}{|c|}{$\begin{array}{c}\text { Oats } \\
\text { monocrop }\end{array}$} & \multicolumn{2}{|c|}{$\begin{array}{c}\text { OOB mixture } \\
2 / 3 \text { oats }+ \\
1 / 3 \text { beans } \\
\end{array}$} & \multicolumn{2}{|c|}{$\begin{array}{c}\text { OBB mixture } \\
1 / 3 \text { oats }+ \\
2 / 3 \text { beans } \\
\end{array}$} & \multicolumn{2}{|c|}{$\begin{array}{c}\text { Beans } \\
\text { monocrop }\end{array}$} \\
\hline & C & $\mathrm{S}$ & C & $\mathrm{S}$ & C & $\mathrm{S}$ & $\mathrm{C}$ & $\mathrm{S}$ \\
\hline Oats & 96 & 108 & 56 & 89 & 42 & 63 & - & - \\
\hline Beans & - & - & 14 & 9 & 23 & 16 & 26 & 24 \\
\hline Total & 96 & 108 & 70 & 98 & 65 & 79 & 26 & 24 \\
\hline
\end{tabular}

Data were obtained from Experiment II only. 

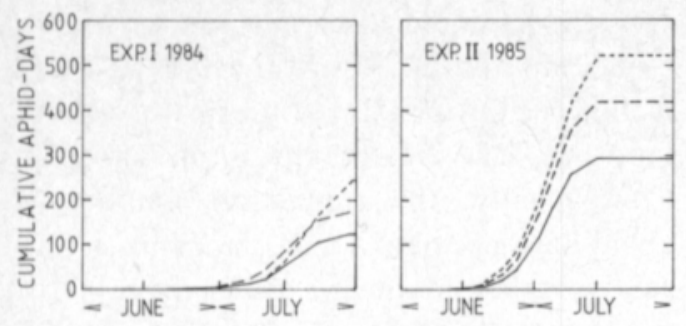

Fig. 8. The cumulative number of aphid days for $R$. padi on oats in the monocrop and mixtures in the experiments I and II in June-July. (monocrop, $(--)$ OOB mixture with $1 / 3$ beans, (-.) OBB-mixture with $2 / 3$ beans.

\section{Pest incidence}

Experiment I. The most abundant cereal aphid on oats was $R$. padi. $M$. dirhodum also reached relatively high densities (Table 3 ). The peak densities of $R$. padi occurred after the anthesis, around mid July. Stand type had no consistent influence on the peak densities (analysis of variance using plot means, lntransformation: $R$. padi $\mathrm{F}=1.1 \mathrm{~ns}, M$. dirhodum $\mathrm{F}=0.7 \mathrm{~ns}, \mathrm{df}=2,4)$. The cumulative number of aphid-days for $R$. padi reached $150-250$ per tiller by August, and they were still slowly increasing at that time. There were no significant differences between stand types $(\mathrm{F}=2.2 \mathrm{~ns}, \mathrm{df}=2,4)$ (Fig. 8).
Frit fly (O. frit) infestation was severe and averaged $48.6 \%$ (proportion of yellowed main stems) at G.S. 39; at that time it was not affected by the cropping pattern to any consistent degree (the interaction crop $\times$ block was significant; LOGLIN, logit $\Delta \mathrm{G}^{2}=12.1^{*}$, $\mathrm{df}=4$ ). Four weeks later, at G.S. 70, the estimated infestation on the adventive tillers averaged $36 \%$ (proportion of yellowed tillers) in the monocrop, $30 \%$ in the OOB mixture and $26 \%$ in the OBB mixture (LOGLIN, logit, $\Delta \mathrm{G}^{2}=8.3^{*}, \mathrm{df}=2$ ).

On beans, A. fabae was more frequent in the monocrop than in the mixtures. The incidence, expressed as the proportion of infested tillers, increased from 18 to 31 July by $30 \%$ in the monocrop, $227 \%$ in the OBB mixture and $131 \%$ in the OOB mixture (LOGLIN, logit, $\Delta \mathrm{G}^{2}=26.9^{* * *}, \mathrm{df}=1$ ). On 18 July the incidences were $66 \%$ and $70 \%$ lower, and on 31 July $14 \%$ and $47 \%$ lower in the OBB and $\mathrm{OOB}$ mixtures than in the monocrop (LOGLIN, logit, $\Delta \mathrm{G}^{2}=32.2^{* * *}$, $\mathrm{df}=2$, interaction crop $\times$ date $\Delta \mathrm{G}^{2}=7.6^{*}, \mathrm{df}=2$ ). The colony size of $A$. fabae, estimated from the score samples, did not increase significantly from 18 to 31 July $(F=2.4 \mathrm{~ns}, \mathrm{df}=1,2)$. The colony size averaged 544 specimens per stem

Table 3. A: Means of the peak densities of $R$. padi per tiller $(\mathrm{n}=150)$ and highest observed numbers of $S$. avenae and $M$. dirhodum per tiller of oats on the monocrop and the mixtures (Experiments I and II). B: Comparison of mean numbers per tiller in control plots (C) and plots sprayed against cereal aphids (S) on 9 July, five days after the last spraying (Experiment II).

\begin{tabular}{|c|c|c|c|c|c|c|}
\hline \multirow[t]{2}{*}{ A: } & \multicolumn{2}{|c|}{ R. padi } & \multicolumn{2}{|c|}{ S. avenae } & \multicolumn{2}{|c|}{ M. dirhodum } \\
\hline & $\begin{array}{c}\text { Exp. I } \\
\text { mean (SE) }\end{array}$ & $\begin{array}{l}\text { Exp. II } \\
\text { mean" }\end{array}$ & $\begin{array}{l}\text { Exp. I } \\
\text { mean }\end{array}$ & $\begin{array}{l}\text { Exp. II } \\
\text { mean }\end{array}$ & $\begin{array}{l}\text { Exp. I } \\
\text { mean }\end{array}$ & $\begin{array}{c}\text { Exp. II } \\
\text { mean }\end{array}$ \\
\hline monocrop & $13.3(1.2)$ & 25.3 & 1.7 & 0.2 & 5.6 & 1.5 \\
\hline OOB mixture & $9.9(1.2)$ & 29.8 & 2.1 & 0.1 & 6.8 & 0.9 \\
\hline OBB mixture & $16.0(1.5)$ & 32.5 & 1.2 & 0.3 & 8.9 & 1.0 \\
\hline \multirow[t]{2}{*}{ B: } & \multicolumn{2}{|c|}{ R. padi } & \multicolumn{2}{|c|}{ S. avenae } & \multicolumn{2}{|c|}{ M. dirhodum } \\
\hline & $\begin{array}{c}\text { C } \\
\text { mean (SE) }\end{array}$ & $\begin{array}{c}\mathrm{S} \\
\text { mean (SE) }\end{array}$ & $\underset{\text { mean }}{\mathrm{C}}$ & $\begin{array}{c}\mathrm{S} \\
\text { mean }\end{array}$ & $\underset{\text { mean }}{\mathrm{C}}$ & $\begin{array}{c}\mathrm{S} \\
\text { mean }\end{array}$ \\
\hline monocrop & $11.5(1.8)$ & $3.1(0.8)$ & 0 & 0 & 0.8 & 1.2 \\
\hline OOB mixture & $19.0(2.7)$ & $3.8(0.9)$ & 0 & 0 & 0.8 & 0.6 \\
\hline OBB mixture & $33.4(6.2)$ & $7.9(1.2)$ & 0 & 0 & 2.2 & 1.0 \\
\hline
\end{tabular}

- score estimation 2-5 July

OOB: $2 / 3$ oats $+1 / 3$ beans; OBB $1 / 3$ oats $+2 / 3$ beans 
(plot means $\mathrm{SE}=24.4, \mathrm{n}=16$, two samples with no colonies), and was not influenced significantly by the stand type $(\mathrm{F}=1.4 \mathrm{~ns}$, $\mathrm{df}=2,2$ ). The numbers of $A$. pisum remained low in all stand types (Table 4).

Altogether 181 bean weevils (Sitona $\mathrm{spp}$.) were trapped in the pitfall traps during 18 May -20 July. Some weevils were always caught during the catching period, but the peak activity occurred in early to mid June, when the beans had 4-6 leaflets, well before flowering. The relative catch was $50 \%$ in the monocrop, $25 \%$ in the OBB mixture, $14 \%$ in the OOB mixture and $11 \%$ in the oats monocrop (LOGLIN, log, $\Delta \mathrm{G}^{2}=64.4^{* * *}$, $\mathrm{df}=3$ ).

Experiment II. Again, R. padi was the most abundant cereal aphid on oats. The densities of $S$. avenae and $M$. dirhodum were low (Table 3 ). The peak numbers of $R$. padi per tiller were double those in Experiment I. The peaks occurred before anthesis, in the first week of July. The highest score estimates for $R$. padi were obtained 2-5 July. Comparison of the treatment means estimated from these values indicate that the numbers per tiller were significantly increased by intercropping (ln-transformation: $\mathrm{F}=10.3^{*}, \mathrm{df}=2,4$ ). By 9
July, the densities had already decreased in the monocrop and OOB mixture, but were still high in the OBB mixture (In-transformation: $\mathrm{F}=10.5^{*}$, $\mathrm{df}=2,4$ ) ('controls' in Table 3). Consequently, the cumulative number of aphid-days per tiller for $R$. padi was significantly higher in the mixtures than in the monocrop ( $\left.\mathrm{F}=10.7^{*}, \mathrm{df}=2,4\right)$ (Fig. 8). Deltamethrin spraying significantly lowered the $R$. padi densities in all stand types (In-transformation, within-factor: $\mathrm{F}=26.2^{* *}, \mathrm{df}=1,6$ ) (Table 3). - The infestation of oats by frit fly (O. frit) was negligible.

The numbers of aphids on beans remained low (Table 4). The relatively high figure for the mean density of $A$. fabae in the monocrop is due to the presence of a single heavilyinfested stem in the sample. The decreasing trend in the incidences of $A$. fabae from monocrop to OOB mixture, similar to that in Experiment I, was evident but not significant (LOGLIN, logit, $\Delta \mathrm{G}^{2}=0.3 \mathrm{~ns}, \mathrm{df}=2$ ). The numbers of aphids in the sprayed plots were negligible.

Some notching of bean leaves by Sitona sp. weevils was observed. Mixed cropping decreased the relative rate of notching by $40 \%$ (OBB) and $55 \%$ (OOB) (LOGLIN, logit,

Table 4. Mean numbers per plant and incidences $(\mathrm{p}=$ proportion of occupied stems) of $A$. fabae, mean numbers of $A$. pisum per plant and mean numbers of Sitona notches per leaf (most lowest leafs, Experiment II only) on field beans on the monocrop and the mixtures.

\begin{tabular}{|c|c|c|c|c|c|c|c|c|}
\hline \multirow[t]{3}{*}{ Exp. I (1984)' } & \multicolumn{4}{|c|}{ A. fabae } & \multicolumn{2}{|c|}{ A. pisum } & & \\
\hline & \multicolumn{2}{|c|}{18 July } & \multicolumn{2}{|c|}{31 July } & \multirow{2}{*}{$\begin{array}{l}18 \text { July } \\
\text { mean }\end{array}$} & \multirow{2}{*}{$\begin{array}{l}31 \text { July } \\
\text { mean }\end{array}$} & & \\
\hline & mean & $\mathrm{p}$ & mean & $\mathrm{p}$ & & & & \\
\hline monocrop & 148.6 & 0.29 & 249.0 & 0.38 & 2.6 & 0.3 & & \\
\hline OBB mixture & 45.3 & 0.10 & 234.3 & 0.33 & 2.1 & 0.1 & & \\
\hline OOB mixture & 48.0 & 0.09 & 94.5 & 0.20 & 4.2 & 0.0 & & \\
\hline \multirow{3}{*}{$\begin{array}{l}\text { Exp. II } \\
\text { (11 July 1985) }\end{array}$} & \multicolumn{4}{|c|}{ A. fabae } & \multicolumn{2}{|c|}{ A. pisum } & \multicolumn{2}{|c|}{ Sitona sp. notches } \\
\hline & \multicolumn{2}{|c|}{ control } & \multicolumn{2}{|c|}{ sprayed } & \multirow{2}{*}{$\begin{array}{c}\text { control } \\
\text { mean }\end{array}$} & \multirow{2}{*}{$\begin{array}{c}\text { sprayed } \\
\text { mean }\end{array}$} & \multirow{2}{*}{$\begin{array}{c}\text { control } \\
\text { mean }\end{array}$} & \multirow{2}{*}{$\begin{array}{c}\text { sprayed } \\
\text { mean }\end{array}$} \\
\hline & mean & $\mathrm{p}$ & mean & $\mathrm{p}$ & & & & \\
\hline monocrop & 14.2 & 0.33 & 0.3 & 0.10 & 2.5 & 0.2 & 1.0 & 0.4 \\
\hline OBB mixture & 1.1 & 0.30 & 0.3 & 0.10 & 0.2 & 0.1 & 0.5 & 0.3 \\
\hline OOB mixture & 1.5 & 0.27 & 0 & 0 & 0.5 & 0 & 0.5 & 0.1 \\
\hline
\end{tabular}

" no data available from sprayed plots.

OOB: $2 / 3$ oats $+1 / 3$ beans; OBB $1 / 3$ oats $+2 / 3$ beans 
$\Delta \mathrm{G}^{2}=9 \cdot 6^{* *}, \mathrm{df}=2$ ). Deltamethrin spraying reduced notching by an average of $59 \%$ in all crop types (LOGLIN, logit, $\Delta \mathrm{G}^{2}=15.6^{* * *}$, $\mathrm{df}=1)$ (Table 4).

\section{Discussion}

\section{Seed yields}

The experiments consisted of replacement series in which the interspecific and intraspecific components of plant interactions are confounded. Thus, no conclusions can be drawn concerning either optimum population densities or the relative importance of inter/ intraspecific competition. The advantage in the biological dimension was interpreted in terms of the land equivalent ratio, LER, which serves to illustrate land-use efficiency in mixtures as compared to monocrops; it lacks explanatory value.

In the very poor growing conditions late in the season in 1984, mixed cropping with oats was more reliable than monocropping beans, and the yield advantage in terms of LER was clear. As the relative yield of oats was not decreased by mixed cropping, the net result favoured this over monocropping. During the normal growing season in 1985, combined with soil of high fertility (oats in the monocrop showed no response to an increase in $\mathrm{N}$-fertilization; unpublished results from an adjacent experiment), mixed cropping had no clear advantage over monocropping. The bean yield was very poor. The results support the finding of high variation in the yield of grain legume, irrespective of cropping pattern, as well as the improvement in yield stability by mixed cropping with cereals (VARIS et al. 1982). A proper study on reliability would require a long series of experiments carried out over several seasons. However, some degree of confirmation was obtained for the current recommendation of mixed cropping of field beans with oats in Finnish conditions.

Mixed cropping increased the nitrogen content of the oat seeds as well as the bean seeds.
This finding is consistent with earlier results on mixed cropping of oats with grain legumes. The nitrogen content of the cereal component rises consistently, whereas the legume component responds more variably (BENGTSSON 1973, VARIS 1983, VARIS et al. 1981). In experiments carried out by MELA and PAATELA (1974) with Sisu oats, the stand density per se did not affect the nitrogen content of the seeds. Although the influence of stand density was not controlled in the experiments reported here, or in the earlier Finnish reports, it can be concluded that the increase in the nitrogen content of oats in the legume mixtures is a true intercropping effect, and can be explained by interspecific complemantarity in the nitrogen uptake. In the case studied here, the oat monocrop produced a total nitrogen output that was only slightly higher than the input as fertilizer, but in the mixtures the output/input ratio varied around $200 \%$.

\section{Formation of yield}

In Experiment I the seed moisture content did not fall to acceptable levels in any of the crop types, and did not depend on the cropping pattern; the weather factors dominated the outcome. Experiment II confirmed the earlier findings that mixed cropping delays the ripening of oats, and hastens the ripening of beans (e.g. VARIS 1983).

The yield component of oats which was the most sensitive to mixed cropping was the number of panicles per plant: tillering was the higher the lower the proportion and density of oats in the mixture. MARTIN and SNAYDON (1982) obtained a similar result for barley intercropped with field beans. The result suggests that tillering of oats takes place before the beans attain a competitive capacity sufficient to compensate for the low total plant density of the mixtures. Thus the response could not be caused by interspecific interaction, but simply by the lower initial plant and biomass density in the mixtures. This explanation is in accordance with the result of Mela and PaAtela (1974) in that tillering 
sharply increases when the density of an oat crop decreases below $300-400$ plants $/ \mathrm{m}^{2}$.

On tillers the average size of the panicles was only ca. $2 / 3$ of that on the main stems. According to Mela and PaAtela (1974), the panicle size on the adventive tillers of sparse monocrops can fall to $1 / 6$ of those on the main stems. In the poor growing conditions in Experiment I, the increase in the proportion of panicles produced by tillers resulted in a decrease in the overall size of panicles, although the average size of the panicles of the main stems or tillers was not affected in mixed cropping. However, in the more normal conditions in Experiment II, the increase in the number of panicles per plant in the mixtures was followed by an increase of overall panicle size, not a decrease as predicted by the hypothesis of negative correlations of the yield components.

The reduced average panicle size, when not compensated for by other components of the yield, decreases the harvest index and thus the efficiency of resource usage in yield formation (cf. Mela and PaAtela 1974). In addition to the relative inefficiency, one disadvantage in yielding via tillers may be a decrease in the homogeneity of grain quality if less mature grains with a high hull content become more frequent. One implication of these considerations is that in order both to improve the management properties of the mixtures and to increase the predictability of the final mixture ratio, it would be beneficial to develop oat varieties for mixed cropping with a low susceptibility to tillering. On the other hand, the inherited susceptibility for tillering is an adaptative property of the small grain cereals that allows for considerable variation in the sowing rate and the initial seedling density without affecting the yield.

The seed weight of a component crop usually increases as the mixture proportion decreases. This was true in the case of oats intercropped with field beans (e.g. VARIS 1983) or with peas Pisum sativum L. (e.g. BENGTSSON 1973), but was not observed in the experiments reported here. In fact, the opposite case was indicated by an indirect measurement in Experiment $\mathrm{I}$.

The increased seed weight of field beans caused by mixed cropping is consistent with earlier results (VARIS 1983). During the wet and cool autumn of 1984 , the relative density of harvestable stems was also increased by mixed cropping, and was the main reason for the improvement in the reliability. The pod size and the number of pods per stem were not influenced by the cropping pattern. The results indicate that when intercropped with a more competitive cereal, beans respond in a specific way that cannot be explained by the changes in density alone. The number of pods per stem is usually the yield component that is most sensitive to varying density (ТномР. SON and TAYLOR 1977, BARRY and STOREY 1979, GRAF and RowLAND 1987), whereas pod size is usually the component most stable in the face of environmental variation (DANTU. MA and Thompson 1983; see also Stoddard 1986). Pulli and Vestberg (1981) reported a decrease in both these components as well as in seed weight with an increase in density.

In a competitive situation (full crop), the hypothesis of intra-plant compensation of the temporally sequential yield components sharing a common limited metabolic pool predicts oscillatory dynamics in the number of panicles or pods per plant, the number of seeds per panicle or pod and, finally, seed weight (Adams 1967, Adams and Grafius 1971). In intercropping, the negative correlations of the yield components may not become so pronounced when the intensity of interplant competition is reduced. This assumption implies that in intercropping in replacement series, the yield components may come closer to potential levels than in the case of monocrops.

\section{Pest incidence}

The only pest species found in harmful numbers were the bird cherry oat aphid $(R$. padi), and the frit fly (O. frit) on oats. The increase in cereal aphid numbers per tiller on oats caused by mixed cropping was reported 
and discussed elsewhere, as well as the slower development of the incidence to mean ratio of $R$. padi in the mixtures (Helenius 1989).

$O$. frit infested oats (1984 only) in equal proportions in the monocrop and mixtures early on during the season. In contrast, the late adventitious tillers were more infested in the monocrop than in the mixtures. Discussion of this result would require more detailed information about the tillering of oats in the system studied. The results of ADEsIYuN (1978) indicated that a reduction in oats stand density can decrease the rates of colonization, oviposition and the survival of larvae. On the other hand, a decrease in stand density combined with intercropping by the replacement method promotes tillering and provides more oviposition sites per plant. $O$. frit is very mobile (e.g. NIELSEN 1985), and an experiment with field plots provides a patchy environment where any habitat (crop type) preferences in colonization by adults are likely to be diluted by movement between the patches.

The incidence, but not the average colony size, of $A$. fabae was decreased by mixed cropping. WAY and HeAthcote (1966) studied the influence of monocrop density of beans on A. fabae: on the smaller plants in the dense stands the mean population density per plant was lower than that in the sparse stands, due to a lower incidence times a lower rate of reproduction. It is interesting, however, that the incidence first increased with host density, from $26 \%$ infested plants at a density of 9.3 plants $/ \mathrm{m}^{2}$ to $34 \%$ infested at a density of 34 plants $/ \mathrm{m}^{2}$, and then decreased consistently to $12 \%$ infested plants at a density of 99 plants $/ \mathrm{m}^{2}$ (percentages obtained from Table 3 in Way and Heathcote 1966). CamMELL and WAY (1983) concluded that dense monocrops are likely to be less severely damaged than sparse monocrops, but that undersowing or intercropping could bring about a reduction in incidence and virus spread. Taking the dispersive host-finding behaviour of colonizers into account (KENNEDY et al. 1959), these results support the hypothesis, presented elsewhere in the case of $R$. padi
(Helenius 1989), that intercropping interferes with secondary dispersal after alighting on the crop, primarily via the increased distance between individual host plants. This mechanism would have the greatest effect in replacement intercrops, where the host density is well below the normal density used in monocrops. The consequences of a decrease in the incidence to damage function, even for virus spread, are obvious.

As is the case with $O$. frit, the observations on Sitona in experiments consisting of mosaic crop patches should be interpreted as choice experiments. The reduced notching of bean leaves by Sitona weevils on the intercrop plots confirms the finding of BALIDDAWA (1984). Assuming that the activity of individuals is not influenced by the stand type, the pitfall trap results revealed that the decrease in notching detected in the mixtures was proportional to the decrease in population density in the mixed crop patches as compared to monocrops. The catch in the oats monocrop plots $100 \mathrm{~m}^{2}$ in size, bordering on the plots with beans, was obviously due to the dispersive movements (crawling and flying) of the weevils. - The main damage mechanism could be larval feeding on root nodules, which was not measured in this study.

Sampling for pests other than cereal aphids was not intensive enough to give more than indicative results. The responses of $O$. frit on oats and A. fabae and Sitona spp. on beans would merit further study.

\section{Insecticide treatments in the mixtures}

In 1984, spraying against cereal aphids had no effect on the oat yield. The most likely explanation is that both the cereal aphid numbers and the yield level were too low for any damage to appear. The proportional yield reduction caused by $S$. avenae is related not only to pest numbers but also to the level of attainable yield: it increases as the yield level rises (RABBINGE and Coster 1984, ROERMOND et al. 1986); it is realistic to assume a similar relationship for $R$. padi, too. If the field beans 
respond to the manipulation of cereal aphid numbers via competitive interaction with oats, then the lack of response in 1984 is as expected.

The oat yield level as well as the aphid densities were higher in Experiment II than in Experiment $\mathrm{I}$, and spraying against cereal aphids considerably increased the oat yield. There were signs that the increase was higher in the mixtures than in the monocrop and was associated with a decrease in the bean yield. These indicative results support the hypothesis of compensatory yielding in the mixtures. However, there was also some indication that spraying caused a decrease (although relatively smaller) in the monocrop yield of beans, too. One alternative explanation for the competitive suppression by oats could be a relatively stronger negative effect of spraying on the beans in the mixtures than in the monocrop. If pollinators were repelled by the spraying, repellence could well be stronger in the mixtures with a higher leaf area and more closed canopy than monocrops at the same time during the season. The spraying treatments reduced pod formation in beans, as would be expected if pollinators were harmed; the earliest flowers are the least autofertile ones (BOND and PoulsEn 1983).

The deltamethrin treatments increased the panicle density, panicle size and seed weight of oats, equally in all stand types. It is assumed here that these increases were achieved through the virtually complete elimination of $R$. padi from the treated plots. The aphid populations peaked during the reproductive phase (before anthesis but after the vegetative phase). A further source-sink study would reveal whether an additional sink for assimilates (aphid feeding) combined with a reduced rate of photosynthesis (leaves covered by aphids and honeydew) would result in similar damage at this stage. It is well known that tiller growth and survival are influenced by post tillering conditions as a result of the priority of the main stem in resource allocation. The yield component most sensitive to cereal aphid damage is usually seed weight, but with high aphid densities even the number of grains per panicle or ear can be reduced (RAUTAPÄÄ 1968, Wratten 1975, 1978, Vickerman and Wratten 1979, Hinz and Daebeler 1980, 1982, Kuroli 1983, KIECKHEFER and KANTACK 1986). The possible contribution of the mild infestation by BYDV was not evaluated in this study.

The reduction in the nitrogen content of oats caused by the spraying was evidently primarily due to the increase in seed weight and total yield (c.f. Wratten 1978, VereiJKEN 1979, JAHN et al. 1987). The slightly earlier maturation of the seeds, as indicated by the reduction in the moisture content of oats at harvest, resulting from cereal aphid spraying could simply have been caused by a faster depletion of resources in producing the higher yield.

\section{General conclusion}

The mixed crop system studied here is an example of the profitable use of intercropping in temperate agriculture. It was demonstrated that the process of yield formation is greatly influenced by the choice of cropping pattern. It was also demonstrated that each member of the pest complex of the system is likely to respond to intercropping in an individualistic way that is not attributable to simple oneto-one causalities; a realistic approach to the study of numerical influences based on the stages in pest population dynamics has already been outlined by PERrin (1977).

Ideally, manipulation of pest numbers when studying the dynamics of yield in intercropping must not lead to confounding side effects: manipulation by spraying is likely to be a crude method in most cases. Furthermore, because interspecific competition is a prequisite for compensatory yielding by a component crop, the field experiment should include controls for this. In a system involving competing plant species and a herbivore common to both, the interaction between competition and herbivory may manifest itself in root growth, above ground vegetative growth 
and/or seed production (c.f. BentLeY and WhitTAKER 1979). The results supported the view that the aspects of compensatory dynamics between component crops and the change in damage function due to management adaptation of the host plant should be included in an intercropping study that attempts to evaluate the effects of crop diversification on the

\section{likelihood and nature of pest damage.}

Acknowledgements. The data was compiled by Päivi Ronni and Juha Helenius co-operatively. The manuscript was written by Juha Helenius. The authors thank AnnaLiisa Varis for criticism of the manuscript and John Derome and Sevastiana Ruusamo for linguistic revision. The study was funded by the National Research Council for Agriculture and Forestry and the Tiura Foundation.

\section{References}

Adams, M.W. 1967. Basis of yield component compensation in crop plants with special reference to field beans, Phaseolus vulgaris. Crop Sci. 7: 505-510.

- \& Grafius, J.E. 1971. Yield component compensation - alternative interpretations. Crop Sci. 11: $33-35$.

Adesirun, A. 1978. Effects of seedling density and spatial distribution of oat plants on colonization and development of Oscinella frit (Diptera: Chloropidae). J. Appl. Ecol. 15: 797-808.

Altierı, M.A. \& Letourneau, D.K. 1982. Vegetation management and biological control in agroecosystems. Crop Protection 1: 405-430.

- \& Liebman, M. 1986. Insect, weed, and plant disease management in multiple cropping systems. In: Multiple cropping systems, p. 183-218 (ed. C.A. Francis). New York.

Baker, R.J. \& Nelder, J.A. 1978. The GliM system. Generalized linear interactive modelling, release 3 . The Numerical Algorithms Group. Oxford.

Baliddawa, C.W. 1984. Movement and feeding activity of adult pea leaf weevil, Sitona lineatus L. in an oatbroadbean diculture. Insect Sci. Appl. 5: 33-39.

- 1985. Plant species diversity and crop pest control. An analytical review. Insect Sci. Appl. 6: 479-487.

Barry, P. \& Storey, T.S. 1979. Influence of some cultural practices on the yield, development and quality of field beans (Vicia faba L.). Irish J. Agric. Res. 18: 77-88.

Bengtsson, A. 1973. Försők av samodling av ärter och havre. Lantbr.högsk. Medd. A 200: 1-24.

Bentley, S. \& WhittaKer, J.B. 1979. Effects of grazing by a chrysomelid beetle, Gastrophysa viridula, on competition between Rumex obtusifolius and Rumex crispus. J. Ecol. 67: 79-90.

Bond, D.A. \& Poulsen, M.H. 1983. Pollination. In: The Faba Bean (Vicia faba L.), p. 77-101 (ed. P.D. Hebblethwaite). London.

Cammell, M.E. \& Way, M.J. 1983. Aphid pests. In: The Faba Bean (Vicia faba L.), p. 315-346 (ed. P.D. Hebblethweite). London.

Dantuma, G. \& Thompson, R. 1983. Whole crop phys-

iology and yield components. In: The Faba Bean (Vicia faba L.), p. 143-158 (ed. P.D. Hebblethweite). London.

Graf, R.J. \& Rowland, G.G. 1987. Effect of plant density of yield and components of yield of faba bean. Can. J. Plant Sci. 67: 1-10.

Helenius, J. 1988. Choice of crop species assemblages as a tool in management. An example of intercropping oats and field beans. Ecological Bulletins, 39: 97-98.

Helenius, J. 1989. The influence of mixed intercropping of oats with field beans on the abundance and spatial distribution of cereal aphids (Hom., Aphididae). Agriculture, Ecosystems and Environment, 25: $53-73$.

Hinz, B. \& Daebeler, F. 1980. Auswirkungen eines Haferblattlausbefalls auf Ertrag und Qualităt von Sommergerste. Nachr.bl. Pfl.schutz DDR 34: 5-7.

- \& Daebeler F. 1982. Schadwirkung der Haferblattlaus, Rhopalosiphum padi (L.), an Sommergerste bei geringer Befallstärke. Wiss. Z. Wilhelm-Pieck Univ. Rostock Naturwiss. R. 31: 61-62.

Hovinen, S. 1982. Hankkijan Mikko-härkäpapu. Hankkijan Kasvinjal.lait. Tied. 7. 20 p.

- 1984. Hankkijan Ukko-härkäpapu. Hankkijan Kasvinjal.lait. Tied. 14. 13 p.

Jahn, B., Merbach, W., Freier, B., Kollner, V. \& WetZEL, T. 1987. Untersuchungen zur Wechselwirkung zwischen Haferlaus (Rhopalosiphum padi (L.)) und Weizenpflanze unter Berücksichtigung der ${ }^{15} \mathrm{~N}-\mathrm{Ver}-$ teilung. J. Appl. Ent. 103: 107-111.

Kennedy, J.S., Booth, C.O. \& Kershaw, W.J.S. 1959. Host finding by aphids in the field. II. Aphis fabae Scop. (gynoparae) and Brevicoryne brassicae L.; with a reappraisal of the role of host-finding behaviour in virus spread. Ann. Appl. Biol. 47: 424-444.

KieckHefer, R.W. \& Kantack, B.H. 1986. Yield losses in spring barley caused by cereal aphids (Homoptera: Aphididae) in South Dakota. J. Econ. Entomol. 79: $749-752$.

Kurol, G. 1983. Damage by oat aphids (Rhopalosiphum padi L.) in cereals. Z. Angew. Ent. 96: $463-469$. 
Litsinger, J.A. \& MoOdy, K. 1976. Integrated pest management in multiple cropping systems. ASA (American Society of Agronomy) Spec. Publ. 27: 293-316.

LOWE, H.J.B. 1984. The assessment of populations of the aphid Sitobion avenae in field trials. J. Agric. Sci. (UK) 102: 487-497.

MARTIN, M.P.L.D. \& SnAYdon, R. 1982. Intercropping barley and beans. I. Effects of planting pattern. Exp. Agric. 18: 139-148.

Mead, R. \& Willey, R.W. 1980. The concept of a Land Equivalent Ratio and advantages in yield from intercropping. Exp. Agric. 16: 217-228.

Mel.A, T. \& PaAtela, J. 1974. Grain yield of spring wheat and oats as affected by population density. Ann. Agric. Fenn. 13: 161-167.

NielsEN, L.B. 1985. Differential flight behaviour of Oscinella spp. (Dipt., Chloropidae). Z. Angew. Ent. 100: $392-398$

Norton, G.H. 1975. Multiple cropping and pest control. An economic perspective. Meded. Fac. Landb.vet. Rijksuniv. Gent 40: 219-228.

Oyejola, B.A. \& MeAd, R. 1982. Statistical assessment of different ways of calculating land equivalent ratios (LER). Exp. Agric. 18: 125-138.

Perrin, R.M. 1977. Pest management in multiple cropping systems. Agro-Ecosystems 3: 93-118.

Pulli, S. \& Vestberg, M. 1981. Genetic and management adaptation of field bean (Vicia faba L.) in Finland. J. Scient. Agric. Soc. Finland 53: 328-340.

Rabiinge, R. \& Coster, G. 1984. Some effects of cereal aphids on growth and yield of winter wheat. In: Pest control: recent advances and future prospects (ed. P. Bailey \& D. Swincer). Proc. 4th Australian Appl. Ent. Res. Conf., 24-28 Sept. Adelaide, Australia. p. 163-169. Adelaide.

RAO, M.R. \& WILley, R.W. 1980. Evaluation of yield stability in intercropping: studies on sorghum/pigeon pea. Exp. Agric. 16: 105-116.

RAUTAPÁ, J. 1968. Changes in the yield and protein quantitiy of oat caused by Rhopalosiphum padi (L) (Hom., Aphididae). Ann. Agr. Fenn. 7: 95-104.

Risch, S.J., Andow, D. \& Altieri, M.A. 1983. Agroecosystem diversity and pest control: data, tentative conclusions, and new research directions. Environmental Ent. 12: 625-629.

Roermond, H.J.W. van, Groot, J.J.R., Rossing, W.A.H. \& RABBingE, R. 1986. Calculation of aphid damage in winter wheat, using a simulation model. Meded. Fac. Landb., Rijksuniv. Gent 51/3a: 11251130.
RUPPEL, R.F. 1983. Cumulative insect days as an index of crop protection. J. Econ. Ent. 76: 375-377.

Stoddard, F.L. 1986. Effects of irrigation, plant density and genotype on pollination, fertilization and seed development in spring field beans (Vicia faba L.). J. Agric. Sci. (UK) 107: 347-355.

Thompson, R. \& TAYLoR, H. 1977. Yield components and cultivar sowing date and density in field beans (Vicia faba). Ann. Appl. Biol. 86: 313-320.

Tottman, D.R. \& Broad, H. 1987. The decimal code for the growth stages of cereals, with illustrations. Ann. Appl. Biol. 110: 441-454.

Trenbath, B.R. 1976. Plant interactions in mixed crop communities. ASA (American Society of Agronomy) Spec. Publ. 27: 129-169.

- 1977. Interactions among diverse hosts and diverse parasites. Ann. New York Acad. Sci. 287: 124-150.

VARIS, E. 1983. Hărkăpavun seosviljely. In: Biologinen typensidonta peltokasvien viljelyssă. Suomen Akatemian Sopimustutk. 383 Loppur. p. 149-174.

-, Hovinen, S. \& Kansanen, P. 1981. Födersädens kvalitet i trinsădesblandningar. In: Nordisk Cerealistförbund XXI Kongr. p. 244-256.

-, Hovinen, S., Kansanen, P. \& Kauppila, R. 1982. Legumes in Finnish agriculture. II Nat. Symp. Biol. Nitr. Fix. p. 219-231. Helsinki.

VereiJKen, P.H. 1979. Feeding and multiplication of three cereal aphid species and their effect on yield of winter wheat. Agr. Res. Rep. 888. 58 pp. Pudoc, Wageningen.

Vickerman, G.P. \& Wratten, S.D. 1979. The biology and pest status of cereal aphids (Hemiptera: Aphididae) in Europe: a review. Bull. Ent. Res. 69: 1-32.

WAY, M.J. \& HeAthCotE, G.D. 1966. Interactions of crop density of field beans, abundance of Aphis fabae Scop., virus incidence and aphid control by chemicals. Ann. Appl. Biol. 57: 409-423.

WILLEY, R.W. 1979. Intercropping - its importance and research needs. Field Crop Abstr. 32: 1-10, 73-85.

de Wir, C.T: 1960. On competition. Versl. Landbouwk. Onderzoek. 66.8. 82 p. Wageningen.

WRATTEN, S.D. 1975. The nature of the effects of the aphids Sitobion avenae and Metopolophium dirhodum on the growth of wheat. Ann. Appl. Biol. 79: 27-34.

- 1978. Effects of feeding positions of the aphids Sitobion avenae and Metopolophium dirhodum on wheat yield and quality. Ann. Appl. Biol. 90: 11-20.

Ms received March 15, 1988 


\section{SELOSTUS}

\section{Sadonmuodostus ja tuholaisten esiintyminen kauran ja härkäpavun seoskasvustoissa}

\author{
Juha Helenius ja Päivi Ronni \\ Helsingin yliopisto, Maatalous- ja \\ metsäelaintieteen laitos, \\ $00710 \mathrm{Helsinki}$
}

Kahdessa kenttäkokeessa vuosina 1984 ja 1985 selvitettiin kauran (Puhti) ja härkăpavun (Mikko) sekaviljelyn vaikutusta satoisuuteen ja sadonmuodostukseen sekă tuholaisten runsauteen puhdaskasvustoihin verrattuna. Tavoitteena oli myős testata hypoteesia lajien vălisestă satokompensaatiosta tilanteessa, jossa tuholainen vioittaa seoskomponenteista vain toista. Koejäsenet olivat puhdaskasvustot ja korvausperiaatteen (replacement series) mukaisesti perustetut seokset, joissa oli joko $1 / 3$ kauraa $+2 / 3$ papua tai $2 / 3$ kauraa $+1 / 3$ papua normaalikylvőmaaărästă. Lisăksi koetekijănă oli kauran tuholaisen, tuomikirvan Rhopalosiphum padi, vioituksen intensiteetti, jota manipuloitiin insektisidiruiskutuksin (verranteet vs. ruiskutetut ruudut).

Ensimmăisessä kokeessa (1984) kasvuolot olivat epäedulliset etenkin loppukauden märkyydestä johtuen; lisăksi tuomikirvojen lukumäärät kauran versoilla jäivăt suhteellisen pieniksi. Insektisidikäsittelyllă ei ollut vaikutusta satoihin tai pinta-alavastaavuussuhteena (LER-indeksi) mitattuun seosviljelytehoon. Pavun seosviljelyteho muodostui positiiviseksi, mutta kauran jăi negatiiviseksi. Toisessa kokeessa (1985) kasvuolot suosivat kauraa. Ruiskuttamattomissa ruuduissa seosviljely ei kum- mallekaan lajille ollut merkitsevästi edullisempaa tai epäedullisempaa kuin puhdaskasvustojen viljely. Tuomikirvan torjunta muutti seoskomponenttien kilpailusuhdetta kauran eduksi; kauran seosviljelyteho kohosi positiiviseksi $(\mathrm{p}<0.05)$ ja pavun seosviljelyteho laski (lähes merkitsevă tulos, $\mathrm{p}=0.08$ ). Tulos tukee hypoteesia, jonka mukaan lajienvälinen kompensoiva satodynamiikka on sekakasvustojen viljelyvarmuuden osatekijä.

Satokomponentteja koskevien tulosten perusteella pảăteltiin, että seosviljelyn vaikutuksessa kauran sadonmuodostukseen maaăraaăvănă on lajinsisăinen kilpailu, kun taas pavun sadonmuodostus on ensisijaisesti lajienvälisen kilpailun säătelemäă. Tämă johtopaaătős tukee aikaisempia suomalaisia tuloksia kauran vallitsevuudesta härkăpapuseoksissa.

Seosviljelyssả tuomikirva esiintyi kauran versoilla runsaampana kuin kauran puhdaskasvustoissa. Papukirvan Aphis fabae keskimaaăräinen koloniakoko ei seosviljelyssă muuttunut, mutta saastuneiden versojen osuus laski. Seosviljely văhensi hernekărsăkkăăn Sitona spp. aikuisten syöntivioitusta pavussa. Myös kahukärpäsen Oscinella frit aiheuttaman vioituksen esiintymisessä havaittiin eroja kasvustotyyppien vălillă. 